6-20-1995

\title{
Acid-Base Chemical Mechanism of Aspartase From Hafnia alvei
}

\author{
Moon Young Yoon \\ University of North Texas Health Science Center \\ Kim A. Thayer-Cook \\ University of North Texas Health Science Center \\ Anthony J. Berdis \\ Cleveland State University, A.BERDIS@csuohio.edu \\ William E. Karsten \\ University of North Texas Health Science Center \\ Klaus D. Schnackerz \\ University of North Texas Health Science Center
}

See next page for additional authors

Follow this and additional works at: https://engagedscholarship.csuohio.edu/scichem_facpub

Part of the Chemistry Commons

How does access to this work benefit you? Let us know!

\section{Recommended Citation}

Yoon, Moon Young; Thayer-Cook, Kim A.; Berdis, Anthony J.; Karsten, William E.; Schnackerz, Klaus D.; and Cook, Paul F., "Acid-Base Chemical Mechanism of Aspartase From Hafnia alvei" (1995). Chemistry Faculty Publications. 168.

https://engagedscholarship.csuohio.edu/scichem_facpub/168

This Article is brought to you for free and open access by the Chemistry Department at EngagedScholarship@CSU. It has been accepted for inclusion in Chemistry Faculty Publications by an authorized administrator of EngagedScholarship@CSU. For more information, please contact library.es@csuohio.edu. 


\section{Authors}

Moon Young Yoon, Kim A. Thayer-Cook, Anthony J. Berdis, William E. Karsten, Klaus D. Schnackerz, and Paul F. Cook 


\title{
Acid-Base Chemical Mechanism of Aspartase from Hafnia alvei
}

\author{
Moon-Young Yoon, Kim A. Thayer-Cook, Anthony J. Berdis, William E. Karsten, \\ Klaus D. Schnackerz, and Paul F. Cook
}

Aspartase (EC 4.3.1.1) catalyzes the reversible deamination of L-aspartate to yield fumarate and ammonia (16) according to Eq. [1].

$$
\text { Aspartate }=\text { Fumarate }+\mathrm{NH} \text {; }
$$

The enzyme is specific for aspartate and fumarate, but $\mathrm{N}_{2} \mathrm{OH}$ can substitute for ammonia as a substrate $(5$, 12). A variety of divalent metal ions are activators of the reaction including $\mathrm{Mg}^{+}$and $\mathrm{Mn}^{2+}(18)$, and initial velocity studies obtained for the enzyme from Hafnia alvei are consistent with a rapid equilibrium kinetic mechanism in which $\mathrm{Mg}^{+}$binds prior to aspartate, but with a random release of $\mathrm{Mg} 2^{+}, \mathrm{NHt}$, or fumarate (14).

The $\mathrm{pH}$ dependence of kinetic parameters of the $\mathrm{L}$ aspartase-catalyzed reaction from Escherichia coli has been examined in both the amination and deamination directions (12). These authors suggest that aspartase exists in a pH-dependent equilibrium between a high pH form that has an absolute requirement for a divalent metal ion and substrate activation and a low $\mathrm{pH}$ form that does not require activation by either substrate or metal ion. Data were consistent with a group with a pK of about 6.5 that acts as a general base in the direction of aspartate deamination and a general acid in the opposite reaction direction.

Gawron and Fondy (8), using the data ofEnglard (6) and Krasna (13), showed that ammonia is added trans across the double bond of fumarate. Primary deuterium and ${ }^{15} \mathrm{~N}$ and secondary deuterium isotope effect data are consistent with the formation of an intermediate 
carbanion following the abstraction of the $C-3 R$ proton, and this is followed by a rate-determining $\mathrm{C}-\mathrm{N}$ bond cleavage (14). In the latter study, the transition state for $\mathrm{C}-\mathrm{N}$ bond cleavage has been suggested to be intermediate between the carbanion and fumarate.

In this paper the $\mathrm{pH}$ dependence of kinetic parameters for the $\boldsymbol{H}$. alvei aspartase are examined in both reaction directions in the presence and absence of $\mathrm{Mg} 2+$ to allow comp rison to the enzyme from $E$. coli (12). In addition, the washin of deuterium from D20 to aspartate during turnover has been measured. Data are discussed in terms of an overall mechanism for aspartase.

\section{METHODS AND MATERIALS}

Chemicals and enzyme. $H$ alvei aspartase (1 unit/mg) was obtained as a crude preparation from Sigma. The enzyme was purified using a Red A agarose column as suggested by Karsten et al. (11). The purified enzyme had a specific activity of 50 assayed with 20 $\mathrm{mM} \mathrm{MgSO}_{4}$ and $10 \mathrm{mM}$ aspartate at $\mathrm{pH} \mathrm{8,} 100 \mathrm{mM}$ Hepes and was estimated to be $67 \%$ pure by SDS-PAGE.4 L-Aspartate, fumarate, $\mathrm{MgC1}_{2}, \mathrm{NH}_{4} \mathrm{Cl}$, and Hepes were from Sigma, while Ches and Mes were from Ultrol. All other reagents were obtained from commercial sources and were of the highest purity available.

Initial velocity studies. All data were collected using either a Gilford 2600 spectrophotometer connected to a Hewlett-Packard flatbed plotter to plot the time course and its derivative or a Gilford 250 spectrophotometer and a strip chart recorder. The temperature was maintained at $25 \circ \mathrm{c}$ with a circulating water bath with the capacity to heat and cool the thennospacers in the cell compartment. All reactions were carried out in 1-ml cuvettes with a $1-\mathrm{cm}$ light path, which were incubated for at least $10 \mathrm{~min}$ in a water bath prior to initiation of reaction by the addition of aspartase. The progress of the reaction was monitored using the appearance or disappearance of fumarate at $240 \mathrm{~nm}\left(\mathrm{t}_{240}=2550 \mathrm{M} \mathrm{M}^{\prime} \mathrm{cm} \cdot{ }^{\prime}\right)$. Fumarate and aspartate concentrations were corrected for complexation with divalent metal ion using the following dissociation constants obtained at $0.1 \mathrm{M}$ ionic strength: Mg-aspartate, $4 \mathrm{mM}$; Mg-fumarate, $10 \mathrm{mM}$ (19).

pHstudies. To be certain that the kinetic mechanism in th diretion of fumarate amination is $\mathrm{pH}$ independent and to obtain estimates of the $K_{\text {n }}$ values for fumarate and ammonia, initial velocity

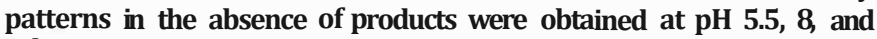
9 by measuring the initial rate at different levels of fumarate and several fixed levels of ammonium ion and at a single saturating concentration of Mg2•. Once the measured kinetic patterns were shown to be $\mathrm{pH}$ independent, saturation curves for aspartate (in the aspartate deamination direction) ar fumarate (in the fumarate amination direction) were obtained at a fixed saturating concentration of the metal ion (and ammonia in the fumarate amination direction) as a function of $\mathrm{pH}$. The $\mathrm{pH}$ was maintained using the following buffers at $100 \mathrm{mM}$ concentrations: Mes, 5.5-6.5 (Pipes replaced Mes for determination of the potassium inhibition constant); Hepes, 6.58.5; Ches, 8.5-9.5. Aspartate and ammonia stock solutions were titrated to the desired $\mathrm{pH}$ to prevent significant differences from the $\mathrm{pH}$ of the buffer used and the final solution $\mathrm{pH}$. The $\mathrm{pH}$ was recorded before and after initial velocity data were recorded; no significant differences were detected.

- Abbreviations used: SOS-PAGE, sodium dodecyl sulfate-polyacrylamide gel electrophoresis; Hepes, N-(2-hydroxyethyl)piperazine-N'-ethanesulfonic acid; Ches, 2-(cyclohexylam.ino)ethanesulfonic acid; Mes, 2-(N-morpholino)ethanesulfonic acid.
Inhibition data were obtained for succinate and $\mathrm{K}$, competitive inhibitors versus aspartate. The substrate concentration was varied, while the Mg2' concentration was maintained saturating. Full inhibi-

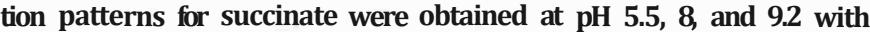
the substrate varied at several different levels of the inhibitor, including zero. Once the competitive nature of the inhibition was determined to be $\mathrm{pH}$ independent, Dixon experiments were performed in which the variable substrate was fixed at a concentration equal to its $K$ and the inhibitor concentration was varied from zero over a range that gave inhibition. The measured $K$ was then divided by 2 to obtain the true $K_{\text {; }}$ Full inhibition patterns were obtained for $K^{\prime \prime}$ at all $\mathrm{pH}$ values except $7,8.87,9.15$, and 9.34, where Dixon experiments were carried out as above.

Deuterium washin. The rate of deuterium incorporation into C$3 R$ of L-aspartate was measured under conditions of turnover by obtaining ${ }^{1 H}$ NMR spectra as a function of time. Spectra were obtained using 2-ml samples in $10 \mathrm{mM}$ Hepes, pD 7.5, at $25^{\circ} \mathrm{C}$ with 5 mM L-aspartate, $20 \mathrm{mM}$ MgSo,, and ca. 0.01 units $/ \mathrm{ml}$ aspartase. Control samples were identical, but excluded aspartase. Spectra were measured on a Bruker AM 300 SWB superconducting spectrometer at $300 \mathrm{MHz}$ for ${ }^{1} \mathrm{H}$, collecting $16 \mathrm{~K}$ data points with a sweep width of $6024 \mathrm{~Hz}$ and a pulse angle of $20^{\circ}$. A total of 12 scans were accumulated per time point. and all spectra were run at $25^{\circ} \mathrm{C}$. Data were also collected in the absence of $\mathrm{Mg} 2$. The $\mathrm{C}-3$ protons of aspartate resonate as an octet near $2.7 \mathrm{ppm}$, while the $\mathrm{C}-2$ proton resonates as a quartet at $3.9 \mathrm{ppm}$, and the product fumarate resonates at 6.5 ppm. No change in the relative intensities of the quartet or octet was observed in the minus enzyme control, and no appearance of fumarate was observed. Incorporation of $3 \%$ deuterium into aspartate could have been detected.

Data processing. Reciprocal initial velocities were plotted against reciprocal substrate concentrations and all plots and replots were linear. Data were fitted using the appropriate rate equations and computer programs developed by Cleland (3). Data from Dixon plot analyses were fitted using Eq. (2). Data obtained for substrate saturation curves obtained for the $\mathrm{pH}$ dependence of the kinetic parameters were fitted using Eq. [3], while data conforming to a rapid equilibrium-ordered kinetic mechanism were fitted using Eq. [41. Data for competitive inhibition were fitted using Eq. [5).

$$
\begin{aligned}
& y=A x+B \\
& v=\operatorname{VAI}(K+A) \\
& \mathrm{u}=\mathrm{VAB} /\left(K_{, .} K_{b}+K_{b} A+A B\right) \\
& \mathrm{u}=\mathrm{VA} /\left(\mathrm{K} \cdot\left[1+1 / K_{;} I+A\right)\right. \\
& \mathrm{SE}=\left[\operatorname { I n t } / \text { Slope } \left\{\left(\mathrm{SE} \text { Int/IntY } \mathbf{I}^{1}+\left(\text { SE Slope } / \text { Slopel }^{2}\right)^{121 / 2}\right.\right.\right.
\end{aligned}
$$

In Eq. (2), $\mathbf{y}$ is $1 / v, x$ is inhibitor concentration, $\boldsymbol{A}$ is the slope, and $\boldsymbol{B}$ is the ordinate intercept. Values for $K$ are obtained by determining the abscissa intercept $(B I A)$ divided by 2 Standard errors were determined using the computer-generated values and Eq. above. In Eqs. [31-151, vis the initial velocity, $V$ is the maximum velocity, $A$, $B$ and $I$ are reactant and inhibitor concentrations, $K$. and $K b$ are the Michaelis constants for $A$ and $B, K$; is the dissociation constant for $A$ and $K_{\text {; }}$ and $\xi$ are slope and intercept inhibition constants, respectively.

Data for pH profiles giving limiting slopes of 1 were fitted using Eq. [7], while data for pH profiles giving limiting slopes of 1 and - 1 were fitted using Eq. [8). Data for $V \mathrm{pH}$ profiles in the presence of Mg2' where $V$ decreases from a constant values at high $\mathrm{pH}$ to a constant value at low $\mathrm{pH}$ were fitted to Eq. [9). The acid side of the VIK $\infty \mathrm{pH}$ profile including the intermediary plateau was fitted using Eq. (101.

$$
\log y=\log [\mathrm{C} / 0+H I K,)]
$$




$$
\begin{gathered}
\log y=\log [\mathrm{C} /<\mathrm{l}+H I K,+\mathrm{K} . / \mathrm{ffi}] \\
\log \mathbf{y}=\log \left(\mathbf{Y}_{\mathbf{L}}+\mathbf{Y}_{\mathbf{H}}[\mathbf{H} / \mathbf{K}, \mathbf{1} /[\mathbf{1}+H ! K, J)\right. \\
\log \mathbf{y}=\log \left(\mathrm{C}\left[\mathbf{l}+\mathbf{H} / \mathbf{K}_{\mathrm{O}} /[1+(H I K .)(1+H / K C))\right)\right.
\end{gathered}
$$

In Eqs. [7] and (8), $\boldsymbol{y}$ is the observed value of the parameter of interest, e.g., VIK $\cdots \circ$ in the absence of Mg2' at a given $\mathrm{pH}, C$ is the $\mathrm{pH}$ independent value of $y, H$ is the hydrogen ion concentration, and $K$ and $K_{2}$ are acid dissociation constants for enzyme, substrate, ar inhibitor functional groups. In Eq. [91, $Y_{i}$, and $Y_{\mathbf{H}}$ are the constant values of $\mathrm{V}$ at low and high $\mathrm{pH}$. respectively, $y$ is the value of $\mathrm{Vat}$ any $\mathbf{p H}, H$ is the hydrogen ion concentration, and $K$, is the acid dissociation constant of the group responsible for the $\mathrm{pH}$-dependent activation. In Eq. [101, $\boldsymbol{y}$ is the observed value of $V I K_{, i p}$ at any $\mathbf{p H}$, $C$ is the $\mathrm{pH}$-independent value $o f j$, $\mathrm{H}$ is the hydrogen ion concentration, and $K ., \kappa_{h}$, and $K$, reflect the three $\mathrm{pH}$-dependent terms for the initial decrease around $\mathrm{pH} 7.5$, leveling off to an intermediary plateau at about $\mathrm{pH} 7$, and the decrease to a limiting slope of 1 at low $\mathrm{pH}$.

\section{RESULTS}

Initial velocity studies in the absence ofproduct and dead-end inhibitors. In the direction of aspartate deamination, all time courses were linear for at least 5 min. In the direction of fumarate amination, time courses obtained at varied fumarate concentration and saturating concentrations of $\mathrm{NHt}$ and $\mathrm{Mg}$ - were complicated by the appearance of a lag in the time course followed by a linear steady-state rate. The lag in the time course was alleviated in all cases by the addition of $1 \mathrm{mM}$ aspartate to the reaction mixture. At $1 \mathrm{mM}$ concentration, aspartate has no inhibitory effect on the reaction. The latter behavior is similar to that reported for the enzyme from $E$ coli $(9,10)$.

Initial velocity patterns obtained by varying the concentration of aspartate at several fixed concentrations of Mg2+ intersect on the ordinate at $\mathrm{pH} \mathrm{8}$, indicating that the kinetic mechanism is equilibrium ordered with $\mathrm{Mg}^{+}$binding prior to aspartate as previously suggested by Nuiry et al. (14). Patterns qualitatively identical to that observed at $\mathbf{p H ~} 8$ were also obtained at $\mathbf{p H}$ 5.5 and 9.2, indicating that the kinetic mechanism in the direction of aspartate deamination is $\mathrm{pH}$ independent. Initial velocity patterns obtained for fumarate amination in the presence of saturating $\mathrm{Mg}$ 2 - and 1 $\mathrm{mM}$ aspartate intersect to the left of the ordinate at $\mathrm{pH}$ 5.5, 8, and 9.2, again suggesting that the kinetic mechanism is $\mathbf{p H}$ independent.

pH dependence ofkinetic parameters in the direction of aspartate deamination. It has been reported by Karsten and Viola (12) that the metal activation of the E.coli enzyme is dependent on the reaction pH. At pH values below 7 , divalent metal ions apparently do not activate, while above this pH divalent metal ion and substrate are essential activators. In view of the similarity in the $H$. alvei and $E$ coli enzymes with respect to substrate activation, it is important to determine

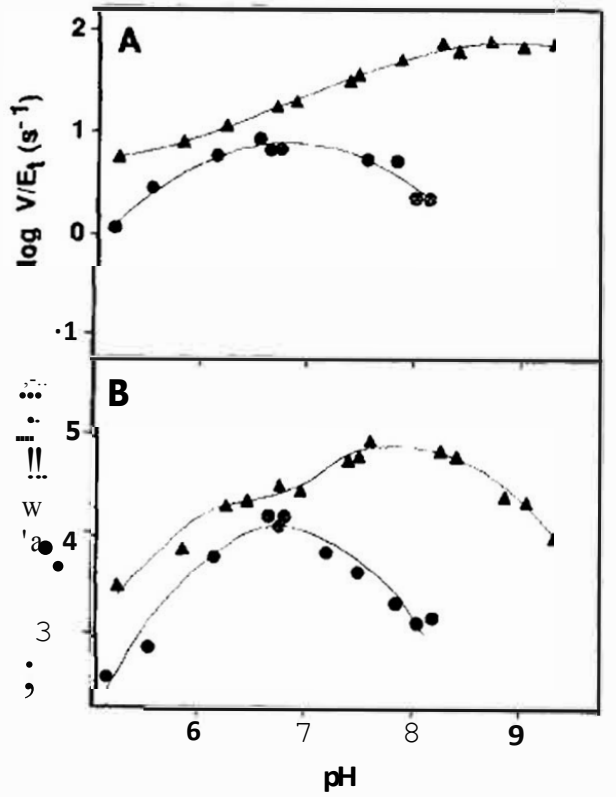

FIG. I. pH dependence of the kinetic parameters for aspartase in the direction of a.spartate deamination in the absence (el and presence $(\&)$ of $20 \mathrm{mM} \mathrm{Mg2 \bullet}$. Data were obtained at $25^{\circ} \mathrm{C}$. The points shown are e,cperimentally determined values. The curves are theoretical in all cases. In the case of $V$ and $V / K, v$ in the absence of $\mathrm{Mg}^{+}$ they are generated from a fit using Eq. [81. while in the presence of $\mathrm{Mgh}^{\mathrm{h}}$, the curve for $V$ is based an parameters estimated from a fit using Eq. (9), while VIK ${ }_{P}^{\circ}$ is generated from fits using Eqs. 181 and (10).

the pH dependence of kinetic parameter plus and minus $\mathrm{Mg}^{+}$.

Kinetic parameters were obtained in the absence and presence of a saturating noninhibitory concentration of $\mathrm{Mg} 2^{+}(20 \mathrm{mM})$. The kinetic parameters obtained under these two conditions are quite different. The maximum velocity in the presence of $\mathrm{Mg}^{+}{ }^{+}$is constant at $\mathrm{pH}$ values above 8 and below 5 (Fig. IA). In the absence of $\mathrm{Mg}^{+}, V_{\text {ma" }}$ decreases at low and high $\mathrm{pH}$ with limiting slopes of 1 and - 1 (Fig. 1A). The pH-independent values of VIE, in the presence ofMg2" at high and low pH are 76 :!: 4 and 6.1 :: $0.3 \mathrm{~s}-{ }^{1}$, respectively, while that in the absence-ofMg2' is $8.0 \pm 0.1 \mathrm{~s}^{-1}$.

The $\mathrm{pH}$ dependence of $V I K_{a s r} P$, was likewise determined in the absence and presence of $20 \mathrm{mM} \mathrm{Mg}{ }^{+}$(Fig. IB). In the presence of $\mathrm{Mg} 2 \cdot$, the $V I K a_{s p}$ profile decreases to a slope of 1 at low $\mathrm{pH}$ with a pK value of 6.3 and a slope of -1 at high $\mathrm{pH}$ with a pK of 8.4. An intermediary plateau is observed between pH 6.5 and 7. In the absence of Mg2 . , the VIKasp profile is also bellshaped with limiting slopes of 1 and -1 , respectively. A pK of 6.6 is observed on the acidic side, identical (within error) to that obtained in the presence of $\mathrm{Mg}^{+}$, but a lower $p K$ value of 7.2 is obtained on the basic side of the profile. The pH-independent values of $V I$ $\mathrm{K}_{\mathrm{as}} \mathrm{rP}$, in the absence and presence of Mg2 - are (1.4 上 
TABLE I

Summary of pK Values Obtained for the Aspartase-Catalyzed Reaction from Hafnia aluei

\begin{tabular}{|c|c|c|c|c|}
\hline Parameter & 20 mM Mg2. & Acidic pK & Basic pK & Activation• \\
\hline \multicolumn{5}{|c|}{ Aspartate deamination } \\
\hline VIE, & + & & & $\begin{array}{l}7.5 \pm 0.2 \\
6.4 \pm 0.1\end{array}$ \\
\hline VIE, & - & $6.0 \pm 0.1$ & $7.6 \div 0.1$ & \\
\hline$V I K \infty, £$ & + & 6.3 : 0.1 & $8.4 \pm 0.1$ & $\begin{array}{l}7.4: 0.2 \\
7.0: 0.2\end{array}$ \\
\hline$V I K{ }^{\prime}, ; E$, & - & 6.6 :!: 0.2 & 7.2 : 0.1 & \\
\hline pKi uccinate & + & $6.3 \pm 0.2$ & $7.8 \neq 0.3$ & \\
\hline pk;poi...ium & + & & $7.6: 0.1$ & \\
\hline \multicolumn{5}{|c|}{ Fumarate amination } \\
\hline VIE, & + & & & $\begin{array}{l}7.6 \pm 0.4 \\
6.4 \pm 0.3\end{array}$ \\
\hline VIE, & - & $7.2 \pm 0.1$ & $9.1 \pm 0.2$ & \\
\hline$V K_{x t} E$ & + & $6.5 \div 0.2$ & - & \\
\hline$V ! K r \bullet . . . E$ & - & $6.4 \pm 0.2$ & $8.7:: 0.2$ & \\
\hline
\end{tabular}

- These $\mathrm{pK}$ values reflect the $\mathrm{pH}$-dependent activation. The first $\mathrm{pK}$ value reflects the initial decrease in activity as the pH is decreased below 8, while the second reflects $V$ leveling off at a lower constant value below pH 6 .

$0.1) \times 10^{4}$ and $(8 \pm 1) \times 10^{4} h_{-} C^{1} s^{-1}$, respectively. All $\mathrm{pK}$ values are summarized in Table $\mathrm{I}$.

pH dependence of kinetic parameters in the direction offumarate amination. The $\mathrm{pH}$ dependence of $\boldsymbol{V}$ for amination was determined in the absence and presence of $20 \mathrm{mM} \mathrm{Mg}{ }^{+}$. In the absence of metal, the $\boldsymbol{V}$ profile is bell-shaped, giving a pH-independent value of $9 \div 1$ $\mathrm{s}^{-1}$ (Fig. 2A). In the presence of the metal ion, $\boldsymbol{V}$ is $\mathrm{pH}$ independent above $\mathrm{pH} 8$ and decreases to a $\mathrm{pH}^{-}$ independent value below pH 5 (Fig. 2A). The pH-independent values of $\mathrm{V}$ at high and low $\mathrm{pH}$ are $39 \pm 6$ and $3.5 \pm 0.6 \mathrm{~s}-1$, respectively.

The $\mathrm{pH}$ dependence of $\mathbf{V} \mathbf{K a m}$ was also measured in the absence and presence of $20 \mathrm{mM} \mathrm{Mg} 2^{+}$. In both cases, $\boldsymbol{V} ! \boldsymbol{K}_{\boldsymbol{a} \boldsymbol{} \boldsymbol{m} \boldsymbol{m}}$ is only slightly $\mathrm{pH}$ dependent. In the absence of $\mathrm{Mg}^{+}$, there is an indication that the parameter decreases below and above the respective $\mathrm{pK}$ values, while in the presence of $\mathrm{Mg}^{+}$only the acidic $\boldsymbol{p K}$ is observed (Fig. 2B). The pH-independent values of $V I$ $K_{\text {rum }}$ in the presence and absence of $\mathrm{Mg}^{+}$are $(3.6 \pm$ $0.4) \times 10^{4}$ and (2.8 :t 0.4$) \times 10^{3} \mathrm{IIC}^{1} \mathrm{~S}^{-}{ }^{1}$, respectively.

pH dependence of the succinate dissociation constant. The $\mathrm{pH}$ dependence of the dissociation constant for succinate, a competitive inhibitor of aspartate, was determined in order to aid in the assignment of those $\boldsymbol{p K}$ values reflecting groups responsible for substrate binding and to determine whether intrinsic $\mathrm{pK}$ values are observed in the $\boldsymbol{V} \boldsymbol{I} \boldsymbol{K}_{\boldsymbol{a}}, \boldsymbol{p} \mathrm{pH}$ profile. The pK; succinate profile (Fig. 3A) decreases at low and high $\mathrm{pH}$ with limiting slopes of 1 and -1 , respectively. The pK; potassium profile was also obtained (Fig. 3B) and exhibits a decrease on the acid side. The pH-independent values of $K$; ouccinate and $K i$ potassium are $11=1$ and $120=10 \mathrm{mM}$, respectively.

Deuterium washin. To determine whether the catalytic base is accessible to solvent once it has abstracted

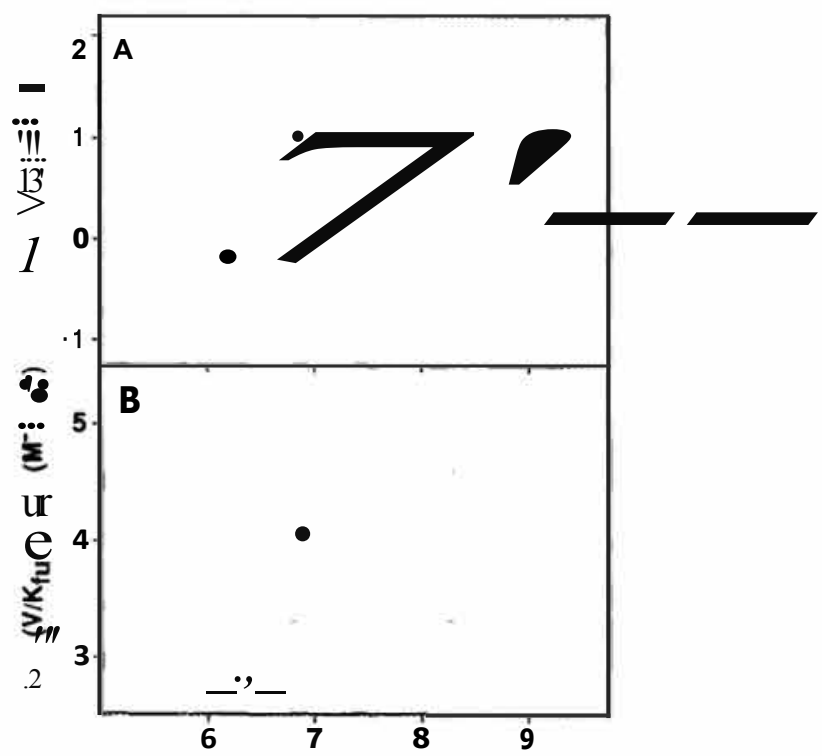

FIG. 2. pH dependence of the kinetic parameters for aspartase in the direction of fumarate amination in the absence (e) and presence (a) of $20 \mathrm{mM} \mathrm{Mg2} \cdot$. Data were obtained at $25^{\circ} \mathrm{C}$. The points shown are experimentally determined values. The curves are theoretical in all cases. In the case of $V$ and $V / K_{\text {um }}$ in the absence of Mg2• they are generated from a fit using Eq. (8), while in the presence of Mg2•, the curve for $V$ is based on parameters estimated from a fit using Eq. (9), while VIK.,p is generated from a fit using Eq. (7). 


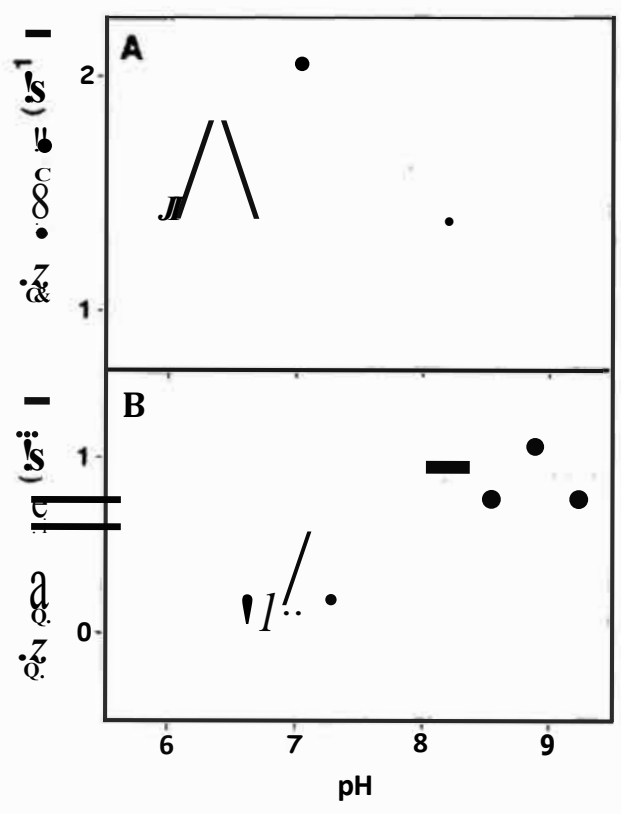

FIG. 3. pH dependence of $1 / K$, for succinate (A) and potassium (B). Data were obtained at $25^{\circ} \mathrm{C}$ as discussed under Methods and Materials. Curves are theoretital from fits to Eqs. B1 (A) and D) (B), while points are experimental values.

the $C-3 R$ proton from $\mathrm{L}$-aspartate, the aspartase reaction was carried out in $D_{2} 0$, and the rate of deuterium washin to the $C-3 R$ position was monitored by ${ }^{1} \mathrm{H}$ NMR. The three regions of importance in the proton NMR spectrum of the aspartate deamination reaction mixture are shown in Fig. 4. The regions of interest are expanded to facilitate visualization. L-Aspartate exhibits an $A B X$ pattem since $C-3 R$ and $C-3 S$ are magnetically nonequivalent. The resonances near $2.7 \mathrm{ppm}$ reflect the C-3 protons. As stated above, the protons are nonequivalent and as a result $C-3 R$ splits $C-3 S$ into a doublet and this doublet is further split by $\mathrm{C}-2$ into a quartet. The $C-3 S$ and $\mathrm{C}-2$ protons also split $C-3 R$ into a quartet, and the $C-3 R$ and $C-3 S$ quartets produce the observed octet. The resonances centered at $3.9 \mathrm{ppm}$ reflect the $C-2$ proton split by $C-3 R$ and $C-3 S$, giving a quartet, while the resonance near $6.5 \mathrm{ppm}$ reflects the two equivalent protons of fumarate. Thus, the relative intensities of the fumarate to aspartate protons can be used as a monitor of the reaction progress. The spectrum shown in Fig. 4A was taken at 15 min after initiation of the reaction by the addition of aspartase, while that shown in Fig. 4B was taken 435 min after initiation of the reaction; the reaction is more than $50 \%$ complete. In addition to the spectra shown, spectra were collected at $0,30,45,60,90,120$, and $180 \mathrm{~min}$. In no case is there evidence of exchange into the $C-3 R$ position. The lack of exchange can most easily be seen from the lack of change in the intensities of the resonances at $\mathrm{C}-2$ relative to one another and to those at $\mathrm{C}-3$. Data collected in the absence of $\mathrm{Mg}^{+}$are identical (not shown).

\section{DISCUSSION}

Interpretation of the $И K_{a s p}$ and $И K_{m} m \mathrm{pH}$ profiles. The VIK for a reactant is the second-order rate constant for conversion of free enzyme and free reactant to products. Thus, the pKs observed in the $V I K_{a s p} \mathbf{p H}$ profiles reflect acid-dissociable functional groups in free $E$ in the absence of $\mathrm{Mg}^{+}$and in free $\mathrm{E}: \mathrm{Mg}$ in its presence. In the direction of ammonia addition to fumarate, $V I$ $\mathrm{K}_{\mathrm{mm}} \mathbf{p H}$ profiles were obtained in the presence of saturating ammonia in the absence or presence of saturating Mg2. and thus reflect E:ammonia and E:Mg:ammonia, respectively.

In the absence of $\mathrm{Mg}^{+}$, a bell-shaped $\mathrm{pH}$ profile is obtained for $V K_{c s}$. Both of the observed $p K$ values must reflect enzyme groups since aspartate exhibits mo pKs in the $\mathrm{pH}$ range 5-9.5. The presence of $\mathrm{Mg}^{+}$ causes an increase in the VIK from $\mathrm{pH} 6.5$ to about 8 and an apparent perturbation in the value of the basic pK from 7.2 to 8.4. No significant change in the value of the acidic $\mathrm{pK}$ is observed. A qualitatively similar behavior is observed in the direction of addition of ammonia to fumarate. The $V ! K_{m m}$ is bell-shaped in the absence of $\mathrm{Mg}^{+}$, giving pKs on both the acid and basic sides. In the presence of $\mathrm{Mg}^{+}$the acidic $p K$ is unchanged, while the basic $\mathrm{pK}$ is apparently perturbed to a value of $>9.5$. Finally, the $\mathrm{pH}$ dependence of the $\mathrm{VI}$

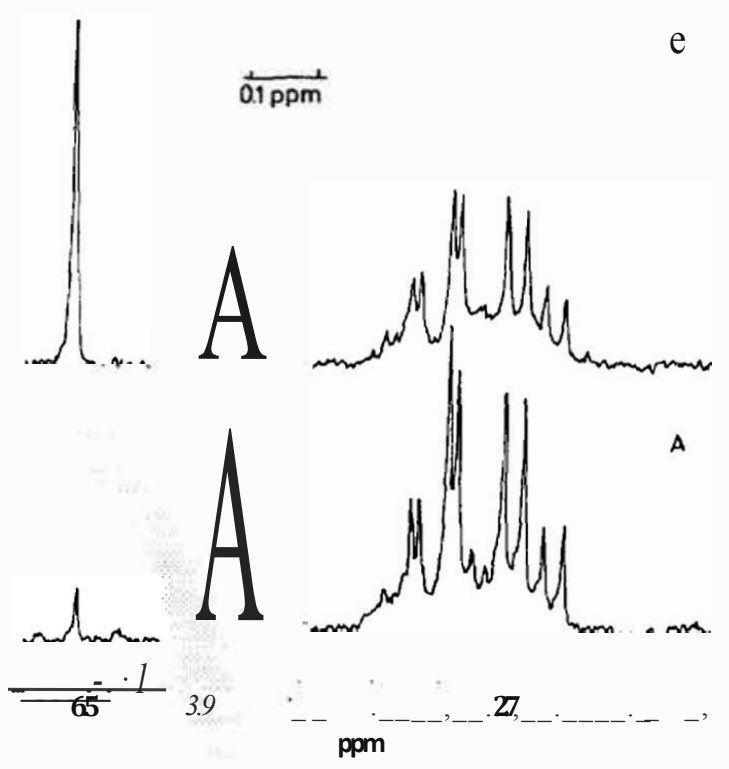

FIG. 4. Portions of the. 1 RNMR spectrum of the reaction mixture for aspartase in the direction of aspartate deamination in the presence of $20 \mathrm{mM}$ Mg2". Spectra were collected as discussed under Methods and Materials. Spectra were collected at $15 \mathrm{~min}$ (A) and $435 \mathrm{~min}$ (B) of reaction. The reaction is about $50 \%$ complete in $\mathrm{B}$. 
$K$ for ammonia has been reported previously over the pH range 6-9.5 (14) at saturating concentrations of fumarate and $\mathrm{Mg}^{+}$. The $V I K$ decreases at high $\mathrm{pH}$ with a $\mathrm{pK}$ of 9.3, consistent with it being the $\mathrm{pK}$ for ammonia.

The bell-shaped nature of the $\mathrm{pH}$ rate profiles obtained in the absence of $\mathrm{Mg}^{+}$, for aspartate and fumarate reflecting the forward and reverse reactions, suggests that the two enzyme groups responsible for the observed pKs function in catalysis. Thus, the two groups would have opposite protonation states in the two reaction directions. These groups are also required in their correct protonation state for the binding of succinate since its dissociation constant increases above and below the same pKs observed in the $V I K_{m p} p H$ profile. The presence of $\mathrm{Mg}^{+}$causes a $\mathrm{pH}$-dependent activation of aspartase superimposed $a$ the bellshaped VIKpH profile. The active enzyme becomes less active below a pK of about 7.5 as observed (uide infra) in the $V, V / K_{, \ldots p}$, and $V / K f u_{m} \mathbf{p H}$ profiles. In addition, potassium binding is only sensitive to the protonation state of the general acid in the direction of aspartate deamination. The general acid group must be unprotonated to bind the positively charged monovalent ion, a mimic of ammonium ion.

Deuterium washin. No washin of deuterium from solvent to aspartate is observed as the reaction progresses to more than $50 \%$ completion in either the absence or presence of $\mathrm{Mg}^{+}$. A reaction mechanism in which a proton is eliminated from the $C-3 R$ position of aspartate prior to the elimination of ammonia has been proposed for aspartase $(14,15)$. The slow step along the reaction pathway is the elimination of ammonia as shown by the observed ${ }^{15} \mathrm{~N}$ isotope effect of $24 \%(1$, 14). Thus, if the active site were accessible to solvent during the catalytic cycle, washin of deuterium to aspartate would be expected since the kinetic mechanism is rapid equilibrium (14). A lack ofwashin of deuterium suggests that the site closes for the catalytic cycle and is not accessible to solvent. The latter has also been shown for fumarase (2) which catalyzes a very similar reaction.

Interpretation of Vmtuprofiles. The $V$ profiles exhibit similar behavior in both reaction directions. In the direction of the elimination of ammonia from aspartate in the absence of $\mathrm{Mg}^{+}$a bell-shaped $\mathrm{pH}$ profile is observed with $\mathrm{pK}$ values very similar to those observed in the $\mathrm{V} / \mathrm{K}_{\mathrm{u}} \mathrm{pH}$ profile in the absence ofMg2 ${ }^{+}$. The two groups likely function in catalysis as discussed above for VI $\mathrm{K}_{\mathrm{aa}_{\mathrm{p}}}$. In the presence of $\mathrm{Mg}^{+}$, a partial change is observed in the $V$ profiles in both reaction directions. A group with a $p K$ of 7.5 is observed that is required unprotonated for optimal activity. The group with a pK of 7.5 is responsible for a pH-dependent activation as it becomes unprotonated. The activation is also ob- served in the $V ! K_{a s p}$ profile as an increase in the $V I K$ between $\mathrm{pH} 6.5$ and 8.

Neither of the two groups observed in $V$ profiles in forward and reverse reactions (minus divalent metal), the $\mathrm{V} / \mathrm{K}_{\mathrm{as}}$ profiles (plus and minus divalent metal), and the V/Krum profile (minus divalent metal) is observed in the $V$ profiles in forward and reverse reactions in the presence of divalent metal. Thus, the two catalytic groups both interact with aspartate which is unlikely given the proposed mechanism (uide infra), are environmentally perturbed when aspartate and $\mathrm{Mg}^{+}$are bound, or a combination of both. Consider first the group that must be unprotonated in the direction of aspartate deamination. Causing the environment surrounding the group to become more hydrophobic would be consistent with the deuterium washin experiments which suggest that the active site is closed and not exposed to solvent under these conditions.

The group that must be protonated for activity in the direction of aspartate deamination is also not observed in the $V$ profile measured in the presence of $\mathrm{Mg}^{+}$. The pK values obtained from the $V$ and $V I K_{a s p} \mathrm{pH}$ profiles in the absence of $\mathrm{Mg}^{+}$are the same within error, while in the presence of metal ion the $\mathrm{V} / \mathrm{K}_{\mathrm{asp}} \mathrm{pKs}$ are not observed in the $V \mathrm{pH}$ profile. Thus, there is apparently a distinctly different conformation of aspartase in the absence and presence ofMg2 - The latter would he consistent with the suggestion based on the NMR relaxation studies of Falzone et al. (7) that $\mathrm{Mn}^{2+}$ binds at an allosteric site. The binding of the divalent metal ion to the allosteric site might be expected to produce a different conformation at the active site. The group with a $p K$ observed on the basic side of the $V I K_{a s p}$ profiles may interact with aspartate and have its pK perturbed (uide infra). Thus, the perturbation of the basic pK observed in the presence ofMg2 ${ }^{+}$is likely a combination of environmental effects and of direct interaction with aspartate.

As a result, in the absence of $\mathrm{Mg}^{+}$, aspartase will bind reactant(s) with apparent equal affinity whether or not the enzyme functional groups reflected in the $V$ and VIK profiles are in their correct protonation state. In the presence of $\mathrm{Mg}^{+}$, reactants apparently bind only to the correctly protonated form of aspartase.

In the direction of fumarate amination, data are qualitatively similar to those obtained in the aspartate deamination reaction direction. In the absence of $\mathrm{Mg}^{+}$, the $V$ decreases at low and high $\mathrm{pH}$ as does $V / K_{f w n}$. Addition ofMg2 ${ }^{+}$causes the basic pKto increase. There are quantitative differences in the $p K$ values observed in the fumarate direction compared to those in the aspartate direction. The differences likely reflect the complexes that are titrated, that is E:aspartate in one direction and E:fumarate:ammonium in the opposite direction.

Taking into account the above data, the mechanism 


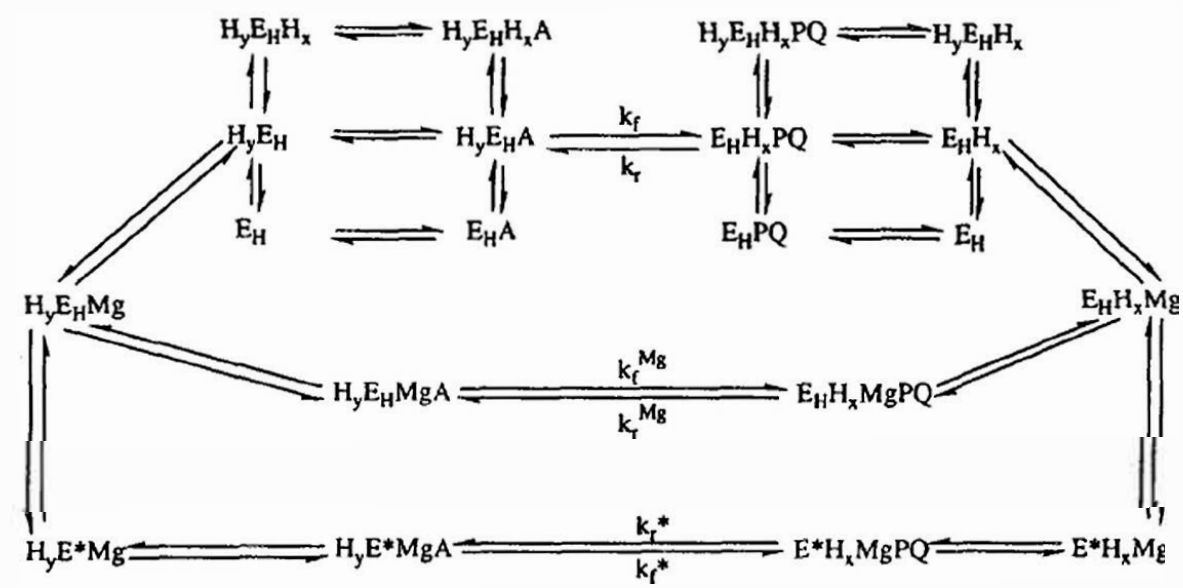

SCHEME 1. Kinetic mechanism of aspartase as a function of pH.

in Scheme 1 best describes the $\mathrm{pH}$ dependence of kinetic parameters. In Scheme $1 E_{H}$ is the least active form of the enzyme that predominates in the absence ofMg2 ${ }^{+}$, while $E^{*}$ is the most active form which predominates in the presence of $\mathrm{Mg}^{+}{ }^{+}$at high $\mathbf{p H}$, and $E_{H: M g}$ is an intermediate form that predominates at low $\mathrm{pH}$ in the presence of $\mathrm{Mg}^{+} . \mathrm{H}_{x}$ and $\mathrm{H}_{y}$ represent the protons on the general base and acid, respectively, when they are protonated. The symbols $A, P, Q$ and $M g$ represent aspartate, $\mathrm{NHt}$, fumarate, and $\mathrm{Mg}^{+}$, respectively. The constants $k r$ and $k$, represent the macroscopic rate constants for the catalytic pathway, where the superscripts $\mathrm{Mg}$ and $*$ reflect the low $\mathrm{pH}$ and high pH Mg-activated forms, respectively.

Acid-base mechanism. A mechanism in which a stabilized carbanion intermediate is formed has been postulated by Nuiry et al. (14) based on isotope effect studies and the observation by Porter and Bright (15) of the high affinity of aspartase for the dianionic form of 3-nitro-L-alanine. A mechanism taking into account the carbanionic intermediate and the above $\mathrm{pH}$ studies is shown in Scheme 2. Aspartate binds to enzyme as the monoanion with both carboxyl groups and the $a$

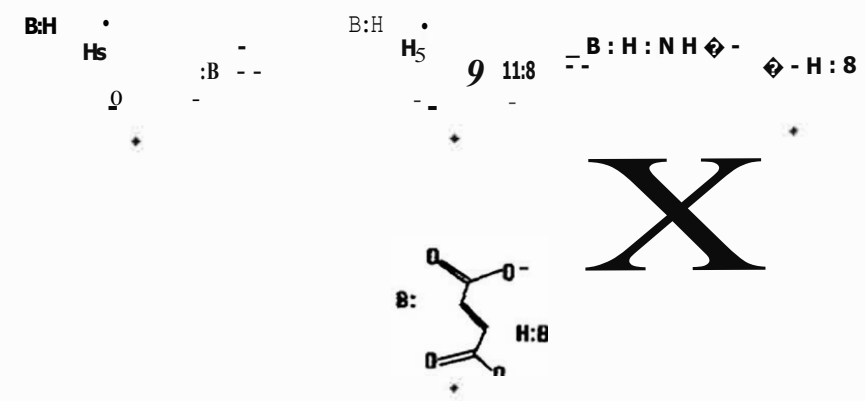

SCHEME 2. Proposed acid-base chemical mechanism of aspartase. amine ionized. ${ }^{5} \mathrm{~A}$ proton is abstracted from C-3 by an enzyme general base with a pK of 6.3-6.6. The pK for the general base is observed in all of the $V$ profiles in the absence of $M g 2^{+}$, all of the VIK profiles in the presence and absence of metal ion, and the pK; ruccinate profile. The resulting carbanion is stabilized by delocalization of electrons into the /J-carboxyl presumably with the assistance of a one ar more positively charged enzyme residues in the vicinity of the .8-carboxyl. Nuiry et al. (14) suggested that $\mathrm{Mg}^{+}$played the role of the Lewis acid coordinated to the ,8-carboxyl of aspartate, but Mg2- is not absolutely required for the reaction and the NMR studies of Falzone et al. (7) indicate that this is unlikely. Thus, an enzyme residue must be responsible for the electrostatic role, but this enzyme group must have a pK higher than 9 , since mo group that can be ascribed to this function is observed in the $\mathrm{pH}$ rate profiles. Ammonia is then expelled with the assistance of a general acid group giving $\mathrm{NH}$; as the product. The general acid is not predicted to protonate the leaving NH3 in the transition state for elimination of ammonia, but rather to trap the expelled $\mathrm{NH}_{8}$ by protonating it once it has been eliminated. The $\mathrm{pK}$ for the general acid is about 7.2 7.6 in the absence of Mg2"', but is increased to a value of 7.6-8.4 in the aspartate deamination direction in the presence of $\mathrm{Mg} 2$ and even higher in the opposite direction. The general acid group is again observed in all of the same $\mathrm{pH}$ rate profiles specified above, for the general base, as well as the pK; potassium profile. -Since the same pK values are observed in the pKi,ixmate and VIK $\mathrm{pH}$ profile, both enzyme groups must be in their optimal protonation state for efficient binding of):eactant in the presence ofMg2+.

\footnotetext{
${ }^{5} \mathrm{~A}$ pK reflecting the cr-amine of aspartate is not observed in the $V I K . ., \ldots, . . . \mathrm{pH}$ rate profile since data were not collected to $\mathrm{pH} \mathbf{1 0}$, the $p K$ value (4). Similar results were presented for the $E$ coli enzyme (12).
} 
The general acid group is likely a neutral acid, since it would be repulsive to the protonated a-amine of aspartate if it were cationic. $A s$ a neutral acid there is also a possibility of hydrogen bonding to the positively charged amine. At the end of a catalytic cycle, both the general base and general acid groups are in a protonation state opposite to that in which they started when aspartate was bound. The $H$. aluei aspartase thus has an acid-base catalytic mechanism similar to that suggested for fumarase which has two catalytic groups, one to accept a proton to form the intermediate and a second to protonate the hydroxyl leaving group (2). In this regard, Bacillus subtilis aspartase and fumarase exhibit $37 \%$ sequence identity (17) as has also been found for the $E$ coli aspartase and class II fumarase.

Similar perturbation of the basic $p K$ is observed for the $E$ coli aspartase (12). These authors interpreted the data based on a $\mathrm{pH}$-dependent conformational activation triggered by Mg2 .; that is, enzyme with the protonated form of the group with a $p K$ of about $7 \mathrm{an}$ the basic side of the $\mathrm{pH}$ profile is more active than that with the group unprotonated. Perturbation of the $\mathrm{pK}$ upon addition of $\mathrm{Mg}^{+}$results in a stabilization of the enzyme form with the group unprotonated. We cannot rule out this explanation as a possibility in the case of the $H$. alvei enzyme. However, in the case of this alternative mechanism, it is not clear why the activity increases to a new constant value prior to decreasing at high $\mathbf{p H}$, rather than simply giving a perturbation of the $\mathrm{pK}$ to higher $\mathrm{pH}$.

Comparison to the E. coli aspartase. The $\mathrm{pH}$ dependence of kinetic parameters in the direction of elimination of ammonium ion from aspartate is qualitatively very similar for the $\boldsymbol{H}$ aluei (this study) and $E$. coli (12) enzymes. The $V ! K_{a s}$ profiles for both enzymes exhibit an increase in rate in the presence of $\mathrm{Mg}^{2}$. at high pH. However, very little metal-dependent increase in activity is observed at low pH for the $E$ coli enzyme, while significant activation is observed over the entire pH range for the $H$. alvei enzyme. As a result, a difference $\mathrm{pH}$ profile is informative in the case of the former, but not in the latter. The $V$ profiles are also quite similar, with the exception that a pK of 9.5 is observed in the presence of saturating Mg2 . for the $E$. coli enzyme, and data were not collected to high enough $\mathrm{pH}$ to define such a $\mathrm{pK}$ for the $H$. aluei enzyme. The biggest differences between the two enzymes appear to be in the fumarate amination direction. The $V$ profiles are similar in that more activation is observed in the fumarate amination direction than in the opposite reaction direc- tion, but almost three orders of magnitude activation is observed for the $E$ coli enzyme, compared to a little over an order of magnitude in the case of the $\boldsymbol{H}$. alvei enzyme. Even more striking are the differences in the $V I K$ profiles for ammonia and fumarate. The $\mathbf{V} / \mathrm{Ka}_{\text {mmonia }}$ profile for the $E$ coli enzyme decreases at low $\mathrm{pH}$ and reflects the $p K$ of ammonia, while that for the $H$. aluei enzyme decreases at high $\mathrm{pH}$ and reflects the $p K$ of ammonia. In addition, the $V / K c_{u m}$ profile for the $E$. coli enzyme decreases at high $\mathrm{pH}$ with a limiting slope of - 2 and reflects the pKs of two enzyme groups, while that for the $H$. aluei enzyme is bell shaped and reflects the same pKs as those observed in the $\mathrm{V} / \mathrm{K}_{\mathrm{as}_{\mathrm{p}}}$ profile. Thus, although the enzymes are very similar in their behavior, the differences discussed above suggest real differences in the acid-base chemical mechanisms of the two enzymes, particularly with respect to the protonation state of ammonia (ammonium ion) as a reactant.

\section{REFERENCES}

1 Anderson, V. E. (1991) in Enzyme Mechanism from Isotope Effects (Cook, P. F., Ed.), pp. 389-418, CRC Press, Boca Raton, FL.

2 Blanchard, J. S., and Cleland, W. W. (1980) Biochemistry 19, 4506."

3. Cleland; W. W. (1979) Methods Enzymol. 63, 103.

4. Dawson; R. M. C., Elliott, D. C., Elliott, W. H.. and Jones, K. M. (Eds.) (1991) Data for Biochemical Research, 3rd ed., pp. 26-27, Clarendon Press, Oxford.

5. Emery, T. F. (1963) Biochemistry 2, 1041.

6. Englard, S. (1958) ,/. Biol. Chem. 233, 1003.

7. Falzone, C. F., Karsten, W. E., Conley, J. D., and Viola, R E. <1988) Biochemistry 27, 9089.

8. Gawron, 0., and Fondy, T. P. (1959)J. Am. Chem. Soc. 81, 6333.

9. Ida, N., and Tokushige, M. (1985) $J$ Bi.ochem. 98, 35.

10. Karsten, W. E., Gates, R. B., and Viola, R. E. (1986) Biochemistry 25, 1299.

11. Karsten, W. E., Hunsley, J. R., and Viola, R. E. (1985) Anal. Biochem. 147, 336.

12 Karsten, W. E., and Viola, R. E. (1991) Arch. Biochem. Biophys. 287, 60.

13. Krasna, A. I. (1958) J Biol. Chem. 233, 1010.

14. Nuiry, I. I., Hermes, J. D., Weiss, P. M. Chen, C.-Y., and Cook, P. F. (1984) Biochemistry 23, 5168.

15. Porter, D. J. T., and Bright, H. J. (1980) J. Biol. Chem. 255, 4772.

16. Quastel, J. H., and Woolf, B. (1926) Biochem. $\rfloor$ 20, 545.

17. Sun, D., and Setlow, P. (1991)J. Bacterial. 173, 3831.

18. Williams, V. R., and Lartigue, D. L. (1967) $\rfloor$ Bi.al. Chem. 242, 2973.

19. Martell, A. E., and Smith, R M. (1979) Critical Stability Constants, Vol. 3, Plenum Press, New York. 